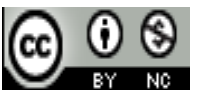

Jurnal Pendidikan IPS Indonesia is licensed under

A Creative Commons Attribution-Non Commercial 4.0 International License

\title{
THE EFFECT OF EXPERIENCE OF SHOPPING AND PERCEPTION OF PRICE ON PERCEPTION OF QUALITY AND PERCEPTION OF VALUE : A CASE STUDY IN SHOPPING CENTER OF MALL PARAGON SOLO, CENTRAL JAVA
}

\author{
Achmad Choerudin $^{1)}$, Margaretha Martina Budhi Utaminingsih ${ }^{2)}$ \\ ${ }^{1)}$ Senior Lecturer, Akademi Teknologi AUB Surakarta and STIE AUB Surakarta, Central Java, Indonesia \\ E-mail:achmadchoerudin77@yahoo.co.id \\ ${ }^{2)}$ Alumnus of Student, Program in Magister Management, STIE AUB Surakarta, Central Java, Indonesia \\ E-mail: ritabudi34@gmail.com
}

\begin{abstract}
The research aims to the effect of experience of shopping and perceived of price on perceived of quality and perceived of value in the shopping center in Mall Paragon Solo, central Java, Indonesia. The collecting data was questionnaires and observations. The sampling was used an accidental sampling of nonprobability sampling technique. The analysis of data using regression. The results of research were (1) the experience of shopping has a negative effect and insignificant on perception of quality, (2) the perception of prices has a negative effect and insignificant on perception the quality, (3) the experience of shopping has a positive effect and significant on perception of value, and (4) the perception of prices has a positive effect and significant impact on perception of value as well as (5) the perception of quality has a negative effect and insignificant on perception of value.
\end{abstract}

Keywords: Experience of Shopping, Perception of Price, Perception of Quality, Perception of Value

\section{INTRODUCTION}

\section{A. Background}

Perceived value is one of the strongest and fundamental marketing approaches for any product or service. It is a matter of opinion and it is completely in the consumer's kingdom. It is defined as the consumer's overall assessment of the utility of a product based upon the perceptions of "what is received and what is given". This definition shows a clear relation of price and quality wherein perceived quality involves consumer judgement about the extent of superiority of the product [1].

The concept of customer value has also drawn increasing attention from both industry executives and marketing academics as a barometer of longterm business performance [2],[3]. Many the shops, has caused consumers have to choose and determine place to shop proper and economically. One factor that emerges is about the perception of value in business with the product is the role of experience shopping. The consumer perceptions of price, quality, and value are considered as core determinants in analyzing shopping behaviour of consumer and choice of a product [4].

The determined that the obtained consumers from shop in a shop certain specified by quality, experience shopping and prices [5]. Dodds and Monroe gave an overview of the relationship between price, quality, and value and found that price has stronger effect on value only when price is present as a cue. Quality and value as cognitive responses to a service experience while satisfaction is an emotional response [6]. The research about consumer behavior is inconsistency between positive and negative results. The research of work available on price, quality and 
value relationship where some studies show positive relationship among these constructs [7],[8],[9],[10],[11] regarding services and food products but [12],[13],[14] showed negative relationship among aforesaid constructs with respect to services as well as products.

Perception of consumers on a low price has caused consumers assumes that price means the quality of their products less well, or if a high price so good quality. The quality is relatively, this means that the quality of can be felt after the purchase process one of the shopping centers in the City of Solo, Mall Paragon in its efforts to enhance visitors transact purchase, need to know the perception related to the shopping center, so that it can be done steps as attempt to anticipate competition between shopping center and to increasing perceived value of consumer.

\section{B. Problems of Study}

1. Do experience of shopping and perception price effect on perceptual the quality?

2. Do experience of shopping and perception price effect on perceptual value?

3. Do experience of shopping and perception price effect on perceptual value and perception the quality?

\section{Objectives of Study}

The purpose of research is to analyze:

a. The effect of experience of shopping on perception prices at shopping center at Mall Paragon Solo.

b. The effect of experience of shopping and perception of price on perception of quality on shopping center at Mall Paragon Solo.

c. The effect of experience of shopping, perception of prices and perception of quality on perception of value on shopping center at Mall Paragon Solo.

\section{Contributions of Study}

This research can be beneficial for:

a. This research could further insight information to shopping centers to better understand the behavior of the consumers in do purchases in online stores. Shopping centers can creates an environment positive shopping by various forms a display and improve services. This can influence consumers to shop and activities of a pleasant shopping. The influence of shopping experience, perception of price and perceptions from the perception of the quality of value, then be used as an ingredient of consideration in making decisions in the future in order to improve the consumer perception of value.

b. To improve their knowledge, experience and insight in the management of marketing and practice of marketing in the field.

c. To add perspectives and literature in the development of science especially management of human resources

\section{Metode}

Methods used is the method survey, with a population of is types of buyers in shopping center of Mall Paragon Solo. The sample was 100 people consumers Mall Paragon Solo and to determine attitude consumers for each consumer perceptions in this research used Scale Likert. The data using technique accidental sampling, that was spreading quisioner in visitors mall who researchers found. The implementation of data collection, the spread and the withdrawal of sample be implemented within a period 2 (two months) in April 2015-May 2015. In this case is the definition of operational:

a. Perception of quality (Y1) is consumer perceptions against a whole quality or excellence a product or services relating to what is expected by the consumer.

b. Perception of value (Y2) is perception value of a product is a perception that involves functional on benefits consumers. The value is crucial to a brand.

c. Experience of shopping (X1) is a function of an atmosphere of a shop, habits as well as the services related to customers, that is all indicators from the notion of existing single in the idea of the consumer [15].

d. Perception of prices (X2) is the relatively that must be paid for the consumers obtain products or services he wants. The positive and negative price find individual differences in response to the extent to which the each of the seven 
dimensions sensitivity prices and concluded that the differences individuals are strongly influence the behavior of purchase [16].

In this research, technique data analysis with regression analysis. The testing the truth of this hypothesis use the regression coefficient in partial or test $\mathrm{t}$ with the formula as following [17]. The formula of research as follow:

Formula $1: \mathbf{Y}_{1}=\boldsymbol{\beta 0}+\boldsymbol{\beta}_{1} \mathbf{X}_{1}+\boldsymbol{\beta}_{2} \mathbf{X}_{2}+\boldsymbol{\epsilon}$

Formula $2: \mathbf{Y}_{\mathbf{2}}=\boldsymbol{\beta} \mathbf{0}+\boldsymbol{\beta}_{\mathbf{1}} \mathbf{X}_{\mathbf{1}}+\boldsymbol{\beta}_{\mathbf{2}} \mathbf{X}_{\mathbf{2}}+\boldsymbol{\beta}_{\mathbf{3}} \mathbf{X}_{\mathbf{3}}+\varepsilon 2$

Explanation :

$\beta_{1}, \beta_{2}, \beta_{3}$, = Coefisient of regression

$Y_{1}=$ Perception of Quality

$\mathrm{Y}_{2}=$ Perception of Value

$\mathrm{X}_{1}=$ Experince of Shopping

$\mathrm{X}_{2}=$ Perception of Value

$\epsilon=$ error

III. RESULT AND DISCUSSION

\section{Instrument Testing}

Table 1. Result of Correlation Testing

"Experince of Shopping $\left(\mathrm{X}_{1}\right)$

\begin{tabular}{|c|c|c|c|}
\hline Items of Question & $\mathrm{r}_{\text {count }}$ & $\mathrm{r}_{\text {table }}$ & Remarks \\
\hline X1_1 & 0.600 & 0.195 & Valid \\
\hline X1_2 & 0.531 & 0.195 & Valid \\
\hline X1_3 & 0.608 & 0.195 & Valid \\
\hline X1_4 & 0.521 & 0.195 & Valid \\
\hline X1_5 & 0.646 & 0.195 & Valid \\
\hline X1_6 & 0.607 & 0.195 & Valid \\
\hline
\end{tabular}

Source: Primary Data, 2015

Correlation items question of variable in that it has value $r$ account larger than $r$ table question is an item being valid in clarifying of that variable.

Table 2. Result of Correlation Testing "Perception of Price" $\left(\mathrm{X}_{2}\right)$

\begin{tabular}{|c|c|c|c|}
\hline Items of Question & $\mathrm{r}_{\text {count }}$ & $\mathrm{r}_{\text {table }}$ & Remarks \\
\hline $\mathrm{X} 2 \_1$ & 0.505 & 0.195 & Valid \\
\hline $\mathrm{X} 2 \_2$ & 0.434 & 0.195 & Valid \\
\hline X2_3 & 0.633 & 0.195 & Valid \\
\hline X2_4 & 0.506 & 0.195 & Valid \\
\hline
\end{tabular}

Table 3. Result of Correlation Testing "Perception of Quality" $\left(\mathrm{X}_{3}\right)$

\begin{tabular}{|c|c|c|c|}
\hline Items of Question & $\mathrm{r}_{\text {count }}$ & $\mathrm{r}_{\text {table }}$ & Remarks \\
\hline X3_1 & 0.434 & 0.195 & Valid \\
\hline X3_2 & 0.660 & 0.195 & Valid \\
\hline X3_3 & 0.544 & 0.195 & Valid \\
\hline X3_4 & 0.546 & 0.195 & Valid \\
\hline X3_5 & 0.370 & 0.195 & Valid \\
\hline X3_6 & 0.400 & 0.195 & Valid \\
\hline
\end{tabular}

Table 4. Result of Corelation Testing

"Perception of Value"( $\left.\mathrm{Y} / \mathrm{Y}_{2}\right)$

\begin{tabular}{|c|c|c|c|}
\hline Items of Question & $\mathrm{r}_{\text {count }}$ & $\mathrm{r}_{\text {table }}$ & Remarks \\
\hline Y_1 & 0.603 & 0.195 & Valid \\
\hline Y_2 & 0.661 & 0.195 & Valid \\
\hline Y_3 & 0.664 & 0.195 & Valid \\
\hline Y_4 & 0.695 & 0.195 & Valid \\
\hline Y_5 & 0.663 & 0.195 & Valid \\
\hline Y_6 & 0.611 & 0.195 & Valid \\
\hline Y_7 & 0.609 & 0.195 & Valid \\
\hline
\end{tabular}

Table 5. Result of Reliability Test

\begin{tabular}{|c|c|c|c|}
\hline Variable & $\begin{array}{c}\text { Cronbach's } \\
\text { Alpha }\left(r_{\text {alpha }}\right)\end{array}$ & Criteria & Remarks \\
\hline $\begin{array}{l}\text { Experince of } \\
\text { Shopping }\left(\mathrm{X}_{1}\right)\end{array}$ & 0,817 & \multirow{4}{*}{$\begin{array}{c}\text { Alpha } \\
\text { cronbach } \\
>0,60 \text { is } \\
\text { reliable }\end{array}$} & Reliable \\
\hline $\begin{array}{l}\text { Perception of } \\
\text { Price }\left(\mathrm{X}_{2}\right)\end{array}$ & 0,713 & & Reliable \\
\hline $\begin{array}{l}\text { Perception of } \\
\text { Quality }\left(\mathrm{X}_{3}\right)\end{array}$ & 0,751 & & Reliable \\
\hline $\begin{array}{l}\text { Perception of } \\
\text { Value }(\mathrm{Y})\end{array}$ & 0,866 & & Reliable \\
\hline
\end{tabular}

2. Result of Linierity Test

\begin{tabular}{|c|c|c|c|c|}
\multicolumn{9}{c|}{ Table 6. Result of Linierity Test } \\
\hline Model & R & $\begin{array}{c}\text { R } \\
\text { Square }\end{array}$ & $\begin{array}{c}\text { Adjusted } \\
\text { R Square }\end{array}$ & $\begin{array}{c}\text { Std. Error of } \\
\text { Estimate }\end{array}$ \\
\hline 1 &, 04 &, 002 &,- 029 & 2,04486513 \\
\hline
\end{tabular}

a. Predictors: (Constant), Perception of

Quality Experince of Shopping, Perception of Price

\section{Path Analysis}

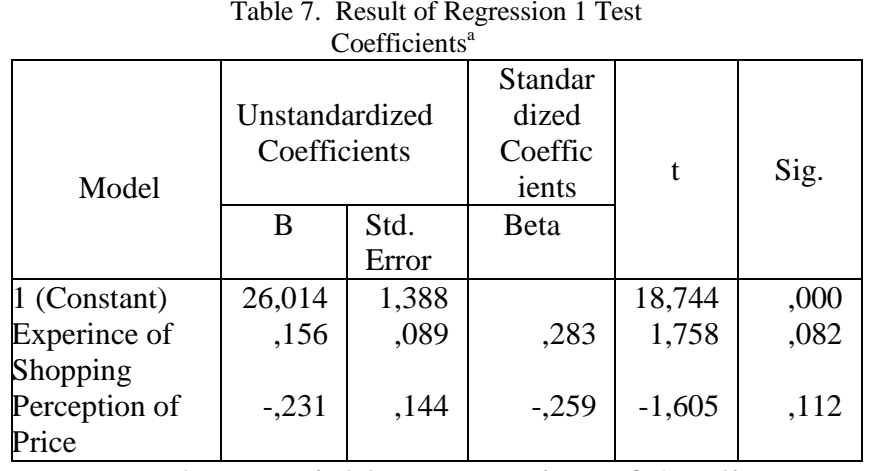

a. Dependent Variable, Perception of Quality

$\mathrm{Y}_{1}=0,283 \mathrm{X}_{1}-0,259 \mathrm{X}_{2}+\epsilon_{1} \rightarrow$

$\mathrm{Y}_{1}=0,283 \mathrm{X}_{1}-0,259 \mathrm{X}_{2}+\epsilon_{1}$

Sig $=(0,082) \quad(0,112)$ 
Table 8. Result of Regression 2 Test

Coefficients $^{\mathrm{a}}$

\begin{tabular}{|l|r|r|r|r|r|}
\hline \multirow{2}{*}{ Model } & \multicolumn{2}{|c|}{$\begin{array}{c}\text { Unstandardized } \\
\text { Coefficients }\end{array}$} & $\begin{array}{l}\text { Standardized } \\
\text { Coefficients }\end{array}$ & \multirow{2}{*}{$\mathrm{t}$} & \multirow{2}{*}{ Sig. } \\
\cline { 2 - 4 } & \multicolumn{1}{|c|}{$\mathrm{B}$} & Std. Error & \multicolumn{1}{|c|}{ Beta } & & \\
\hline 1 (Constan & 2,705 & 2,903 &, 932 &, 354 \\
t) &, 772 &, 088 &, 720 & 8,770 &, 000 \\
$\begin{array}{l}\text { Experince } \\
\text { of }\end{array}$ &, 315 &, 142 &, 182 & 2,223 &, 029 \\
$\begin{array}{l}\text { Shopping } \\
\begin{array}{l}\text { Perception } \\
\text { of Price }\end{array}\end{array}$ &, 047 &, 099 &, 024 &, 480 &, 632 \\
$\begin{array}{l}\text { Perception } \\
\text { of Quality }\end{array}$ & & & & & \\
\hline
\end{tabular}

a. Dependent Variable, Perception of Value

$\mathrm{Y}_{2}=0,720 \mathrm{X}_{1}+0,182 \mathrm{X}_{2}+0,024 \mathrm{Y}_{1}+\epsilon_{2}$

$\mathrm{Sig}=(0,000) * *(0,029) * *(0,632)$

\section{Result of F Test}

Table 9. Result of F Test 1 ANOVA $^{\mathrm{b}}$

\begin{tabular}{|c|c|c|c|c|c|}
\hline Model & $\begin{array}{c}\text { Sum of } \\
\text { Squares }\end{array}$ & Df & $\begin{array}{c}\text { Mean } \\
\text { Square }\end{array}$ & F & Sig. \\
\hline 1 Regression & 14,266 & 3 & 7,133 & 1,611 &, $205^{\mathrm{a}}$ \\
Residual & 429,374 & 97 & 4,427 & & \\
Total & 443,640 & 99 & & & \\
\hline
\end{tabular}

a. Predictors: (Constant), Perception of Price, Experince of Shopping

b. Dependent Variable: Perception of Quality

Table 10. Result of F Test 2 ANOVA $^{\mathrm{b}}$

\begin{tabular}{|l|c|c|c|c|c|}
\hline & $\begin{array}{c}\text { Sum of } \\
\text { Squares }\end{array}$ & Df & Mean Square & F & Sig. \\
\hline 1 & 1269,750 & 3 & 423,250 & 101,02 &, $000^{\mathrm{a}}$ \\
Regression & & & & 2 & \\
Residual & 402,210 & 96 & 4,190 & & \\
Total & 1671,960 & 99 & & & \\
\hline
\end{tabular}

a. Predictors: (Constant), Perception of Quality, Perception of Price, Experince of Shopping

b. Dependent Variable: Perception of Value

\section{Result of Hipotesis Partial Test (Uji t)}

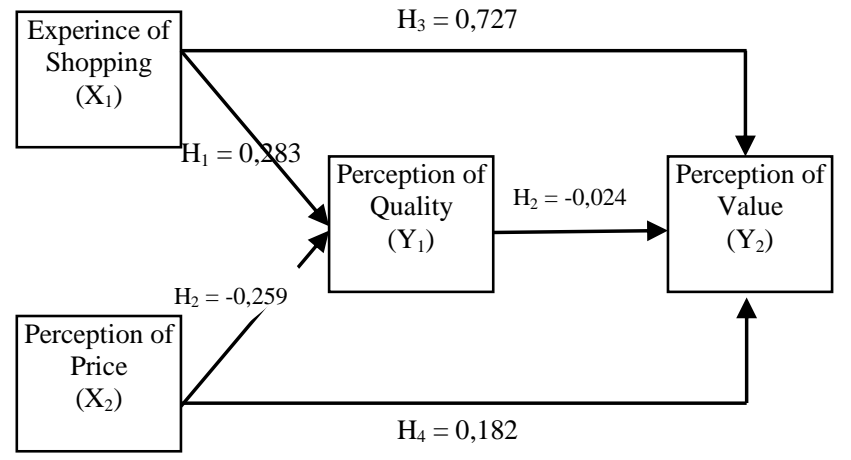

Fig. 1. Result of Hipotesis Partial (Uji t)

1. Hypothesized 1: the experience of shopping has a negative effect and insignificant on perception of quality.

2. Hypothesized 2: the perception of prices has a negative effect and insignificant on perception the quality.

3. Hypothesized 3: the experience of shopping has a positive effect and significant on perception of value.

4. Hypothesized 4: the perception of prices has a positive effect and significant on perception of value.

5. Hypothesized 5: the perception of quality has a negative effect and insignificant on perception of value.

The calculation on performed with statistical analysis to 100 respondents with a questionnaire that produce results test the regression equation is first and second the effect on experience shopping 0,283 while influence perception price $-0,259$ if it multiplied $=0,733$. The results of the study stated that:

The first, based on the calculation on the calculation on obtained value of $t_{\text {account }}=0,727>$ $\mathrm{t}_{\text {table }}=0,182$ and significance was 0,000 at $\alpha=$ 0.05 , thus Ho was rejected, so experience of shopping has a positif effect and significant on perception of value in Mall Paragon Solo. The calculation on obtained value of $t_{\text {account }}=0,864>t$ table $=0,745$ and significance was 0,003 at $\alpha=0.05$, thus Ho was rejected so perception of price has a positive effect and significant on perception of value in Mall Paragon Solo.

The second, based on the calculation on obtained value of $\mathrm{t}_{\text {account }}=0,076>\mathrm{t}_{\text {table }}=0,455$ and significance was 0,001 at $\alpha=0.05$, thus Ho was rejected so perception of quality has a positive effect and significant on perceived of value in Mall Paragon Solo.

The third, based on value of F obtained test value of $t_{\text {account }}=1,611>\mathrm{t}_{\text {table }}=0,205$ and significance at value of 0,000 at $\alpha=0.05$, it hence Ho rejected so there are significant and influence 
between shopping experience, perception prices and perception of quality towards perception of value in Mall Paragon Solo.

The fourth that experience of shopping, perception of price and perception of quality has positive effect and significantly on perception of value on shopping center in Mall Paragon Solo, can be accepted. The finding is supported by

Based on the calculation of value the results of the coefficients determined equation first adjusted $\mathrm{R}$ square (Adjusted $R^{2}$ ) was 0,032. From the these calculations can be concluded that the model be used variables free contributed of $32 \%$ on variables bound, while of $68 \%$ was influenced by a factor of other than variable the treatment, perception brand, perception profit or others. While value of adjusment $\mathrm{R}$ square (Adjusted $R^{2}$ ) at the supermarket determinant of 0,777 , and $77,7 \%$ on variables bound, while of $22.3 \%$ was suppose perception brand, perception profit or others.

\section{Conclusion}

1. Experience of shopping has a positive effect and significant on perception of quality, while perception of prices has a negative effect and significant on perception the quality, it means the higher value of positive the more higher the effect of their, but if value of negative was getting smaller or do not affect.

2. Experience of shopping and perception of prices has a positive effect and significant on perception of value, that means that experience shopping and perception price someone very large their influence on perception value of a goods.

3. Experience of shopping, perception of prices and perception of value has a positive effect and significant on perception of quality, that means that experience of shopping someone, perception of prices and perception of value very large their influence on perception of quality.

\section{REFERENCES}

Zeithaml, V. A. (1988), "Consumer Perceptions of Price, Quality, and Value: A Means-end Model and Synthesis of Evidence," Journal of Marketing 52 (July), 2-22.

Reichheld, F. F. (1993), "Loyalty-Based

Management," Harvard Business Review, 71 (2), 64-72.
Woodruff, R. B. (1997), "Customer Value: The Next Source of Competitive Advantage," Journal of the Academy of Marketing Science, 25 (2), 139-53.

Jacoby, J. and Jerry C. Olison (1985), Perceived Quality. Lexington, MA: Lexington Books.

Rimiyati, Hasnah (2004), "Pengalaman Berbelanja di Supermarket dan Persepsi konsumen atas Harga-Kualitas-Nilai", Tesis Fakultas Ekonomi Universitas Gajah Mada, Yogyakarta

Petrick, J. F. (2004), "The Roles of Quality, Value, and Satisfaction in Predicting Cruise Passengers' Behavioural Intentions," Journal of Travel Research, 42, 397-407.

Oh, Haemoon (2000), "The Effects of Brand Class, Brand Awareness, and Price on Customer Value and Behavioural Intentions," Journal of Hospitality and Tourism Research, 24, 136-62

Hanzaee, K. H. and Yazd, R.M. (2010), "The impact of brand class, brand awareness and price on two important consumer behaviour factors; customer value and behavioral intentions," African Journal of Business Management Vol.4 (17), pp. 3775-3784, 4 December, 2010.

Zielke, Stephan (2011), "Integrating Emotions in the Analysis of Retail Price Images," Journal of Psychology and Marketing, 28 (4), 330-59

Judd, V.C. (2008), "The price-quality relationship: An empirical study of food products," Journal of food products marketing, 6 (1), 11- 24

Edward, Manoj and Sunil Sahadev (2011), "Role of Switching Costs in the Service Quality, Perceived Value, Customer Satisfaction and Customer Retention Linkage," Asia Pacific Journal of Marketing and Logistics, 23 (3), 327-45.

Chen, Zhan and Alan J. Dubinsky (2003), "A Conceptual Model of Perceived Customer Value in E-Commerce: A Preliminary Investigation," Psychology and Marketing, 20 (4), 323-47.

Shifflet, D. K. and V. Bhatia (1997), "Customer Satisfaction is Still Key," Hotel and Motel Management, 7, 24. 
Peterson, Robert A. and William R. Wilson (1985), "Perceived Risk and Price Reliance Schema as Price -Perceived Quality Mediators," in Perceived Quality: How Consumers View Stores and Merchandise, Jacob Jacoby and Jerry C. Olson, eds. Lexington, MA: D.C. Heath and Company, 247-68.

Schiffman and Lazar Kanuk, 2000, Costumer Behaviour, Internasional Edition, Prentice Hall.

Mowen, Jhon (2002). Perilaku Konsumen. Edisi Kelima. Jilid 2. Jakarta : Erlangga.

Sugiyono. (2012). Metode Penelitian Kuantitatif Kualitatif dan R\&B. Bandung: Alfabeta. 